\title{
家庭ごみ有料化における手数料使途の実態 及び情報公開
}

\author{
日笠 希美 $^{1}$ - 金谷 健 $^{2}$ \\ 1 滋賀県立大学学生 環境科学部環境政策・計画学科 \\ （†522-8533 滋賀県彦根市八坂町 2500） \\ 2 正会員 工博 滋賀県立大学教授 環境科学部環境政策・計画学科 \\ 同上 ) \\ E-mail: kanaya@ses.usp.ac.jp
}

\begin{abstract}
家庭ごみ有料化における手数料使途の実態や情報公開の詳細な全国的傾向について，有料化施行時期 が近年（2005 年〜2009 年）の市へのアンケート調查を行い，主に以下のことがわかった．1）手数料収 入は，特別会計でなく一般会計に入るが，使途を「限定なし」の市の割合は $25 \% て ゙ あ り ， 6$ 年前の 59 \%から, 大幅に減少した. 2) 使途項目が, 新規が 3 割程度あり, 有料化の手数料で, 新規に始められた 事業が少なくない，なお継続であっても，事業費が増加している使途項目が約 5 割ある. 3) 手数料使途 内容の決定過程の資料の情報公開，手数料使途実績の情報公開も，ともに約半数の市で実施されている. 4) 手数料使途の情報公開とごみ減量との間には，統計的に有意な関連が認められる.
\end{abstract}

Key Words :household waste, charge , usage of charge, publication of information, questionnaire survey

\section{1. 研究の背景および目的}

環境省は 2005 年 5 月 26 日付けで「廃棄物の減量その 他その適正な処理に関する施策の総合的かつ計画的な推 進を図るための基本的な方針」の一部を改正し，家庭ご みの減量を推進するため,「経済的インセンティブを活用 した一般廃棄物の排出抑制や再生利用の推進，排出量に 応じた負担の公平化及び住民の意識改革を進めるため, 一般廃吂物処理の有料化の推進を図るべきである.」 ${ }^{1)}$ と の方針を明確化した。

また，環境省は 2007 年 6 月には，「一般廃棄物処理有 料化の手引き」2)を策定し, 市町村が有料化の導入又は 見直しを実施する際に, 参考となる手引きとなるように, 有料化において考慮すべき様々な事項（有料化の定義, 導入プロセス, 目的と効果, 手数料の料金体系や料金水 準，手数料収入の使途，円滑な導入・実施に向けた関係 者との連携等）を簡潔にまとめている.

なお 2011 年 3 月公表の環境省調査によると, 2009 年 度実績で, 全国 1750 市町村のうち, 1072 市町村 (61.3\%) で家庭ごみ有料化（粗大ごみ含めず）が実施されている
3). しかし家庭ごみ有料化を実施していない市町村も 4 割近く存在し，これらの市町村が今後，家庭ごみ有料化 の実施の是非や実施内容を検討するにあたり，家庭ごみ 有料化についての様々な知見が有益となるだろう.

家庭ごみ有料化に関してはこれまでに，山川ら ${ }^{4)} レ$ ビュー，Sakai.et.al ${ }^{5)}$ のレビュー，指定袋配布方法とごみ 減量効果との関係 ${ }^{6}$ ，家庭ごみ有料化における料金とご み減量効果 ${ }^{78)}$, 透明・半透明袋制導入とごみ減量効果と の関係 ${ }^{9)}$ ，家庭ごみ有料化における制度設定プロセス及 び料金設定根拠 ${ }^{10)}$ ，パネルデータ分析による有料化制度 設計要因とごみ減量効果との関係 ${ }^{11)}$ ，山谷によるこれま での一連の調査研究をまとめた書籍 ${ }^{12) 133}$ など, 多くの研 究がある.

しかし，家庭ごみ有料化における手数料使途の実態や 情報公開についての研究は少ない，前述の環境省の「手 引き」2)においては,「手数料収入の使途」について,「一 般廃棄物処理の有料化により徵収された手数料について, 有料化の運用に必要な経費の他，適切な使途を定め, 透 明化することが求められる。 なお，一般廃棄物の排出抑 制や再生利用の推進に資寸る使途を定めることで，有料 
化制度への理解を深め, 排出抑制への住民の意識を高め ることが期待できる.」と記載して, 手数料使途の透明化 (情報公開) や拡大の必要性を指摘しているが，手数料 使途の例示や, 手数料使途の実績例 (山谷の研究 ${ }^{14}$ を紹 介）の紹介にとどまっている. なお山谷の研究 ${ }^{14)}$ では, 2005 年 2 月時点での全国アンケートで「手数料収入の使 途」と「手数料収入の運用」のそれぞれについて 1 問ず つ選択式で質問している. また前述の山谷の書籍 ${ }^{13)}$ では, 「手数料収入の使途の「見える化」を」として，5市の 事例を簡単に紹介しているが，全国的な傾向は明らかで はない. 以上のことから, 家庭ごみ有料化における手数 料使途の実態については, 現時点での詳細な全国的傾向 は明らかではなく, 手数料使途の情報公開については, これまでの研究は見当たらない.

そこで, 本研究では, 家庭ごみ有料化における手数料 使途の実態や情報公開の詳細な全国的傾向を明らかにす ることを目的とする.

\section{2. 調查方法}

環境省 HP の「廃棄物処理技術情報 ${ }^{15}$ に掲載されてい る一般廃棄物処理実態調査結果にある計 429 市の家庭ご み有料化実施市のうち, 施行時期が 2005 年から 2009 年 の5年間に当てはまる計 155 市を調査対象とした. なお, 対象市の施行時期を 2009 年までに限定したのは, 最低 1 年分のデータを確保するためである. また, 対象市の施 行時期を 2005 年以降に限定したのは, ある程度以上過去 の資料 (審議会等) が保管されていない可能性を懸念し たためである. なお, 現在全国的に市町村合併が進んで いることを踏まえ，本研究では調査対象を「市」のみに 限定した.

調査は, 調查対象市へのアンケート調查により行った. アンケート票を, 2011 年 9 月 11 月に送付 (郵送・メー ル・FAX) し，110 市から返信があった，なお，回答の 確認及び追加の質問を行うため, 追加アンケート調查も 実施した. アンケートの内容(追加アンケートを含む)は, 表-1 に示寸 (本論文では言及していない内容も含む). アンケートの内容は, 有料化全般に関する事項, 審議段 階及び説明会に関する事項, 手数料収入の使途に関する 事項，今後の課題に関する事項，に大別される.

\section{3. 結果および考察}

\section{（1）手数料使途の実態}

\section{a) 手数料使途の限定の有無}

手数料収入は，一般会計に入るのか，特別会計に入る
のかを質問したところ，広域事務組合予算の 1 市を除く 109 市すべて一般会計であり, 特別会計の市は存在しな かった.

ただし，一般会計と回答した 109 市に, 一一般会計の中 でも，枠を設けて使途をごみ関係に限定」しているか否 かを質問したところ，回答 105 市のうち，「限定あり」が 75\% (79 市)，「限定なし」が 25\%（26 市）であった. また，「限定あり」と回答した 79 市に「その枠の名称」 を質問したところ，71 市から回答があり，うち 64 市が 何らかの名称（例えば，清掃費の特定財源，廃棄物対策 費，環境共生市民協働事業基金）を回答した。この 64 市は, 上記 105 市の $61 \%$ に相当する. この $61 \%$ 以外をす べて「限定なし」とみなしても，「限定なし」は $39 \%$ に なる.

山谷が 2005 年 2 月時点で実施した研究 ${ }^{14)}$ では, 「他の 手数料と同様の一般財源として運用」が $59.4 \%$,「特定財 源化して運用している」が 30.1\%，「基金化している」が 4.8\%，「その他」が 5.7\%である. 本研究の「限定なし」 に対応するのは,「他の手数料と同様の一般財源として運 用」（+「その他」）と推察される. そのため, 山谷の上 記研究結果の回答対象は, 2005 年時点の有料化実施市 270 市のうちの 229 市であり, 本研究の上記結果の回答 対象 105 市とは一致しないため, 単純な比較は困難では あるが, 2005 年以降の 6 年間で, 「限定なし」が減少し たと推察される（59.4\%～65.1\%——25\%〜39\%).

表-1 アンケート内容

\begin{tabular}{|c|c|c|c|}
\hline \multirow{2}{*}{\begin{tabular}{|c|}
\multicolumn{1}{|}{ アンケート内容 } \\
有料化全般に関する事項 \\
\end{tabular}} & \multicolumn{2}{|c|}{ 回答方法 } & \multirow[t]{2}{*}{ 回答数 } \\
\hline & & & \\
\hline 1家庭ごみ処理・有料化の主体について & 選択式 & 単数回答 & $\mathrm{n}=107$ \\
\hline 2 事務組合の構成 & 記述式 & - & $\mathrm{n}=51$ \\
\hline 3 有料化自治体 & 選択式 & 単数回答 & $\mathrm{n}=50$ \\
\hline 4 会計体制 & 選択式 & 単数回答 & $n=110$ \\
\hline \begin{tabular}{l|l}
5 & 一般会計の限定の有無 \\
\end{tabular} & 選択式 & 単数回答 & $\mathrm{n}=109$ \\
\hline \begin{tabular}{l|l}
6 & 限定内容 \\
\end{tabular} & 記述式 & - & $\mathrm{n}=79$ \\
\hline \begin{tabular}{l|l}
7 & 家庭ごみ有料化導入 $\sigma$ 目的 \\
\end{tabular} & 選択式 & 複数回答 & $n=110$ \\
\hline 8 家庭ごみ有料化導入の最大の目的 & 選択式 & 単数回答 & $\mathrm{n}=89$ \\
\hline \begin{tabular}{l|l}
9 & 手数料徴収方法
\end{tabular} & 選択式 & 単数回答 & $\mathrm{n}=110$ \\
\hline 10 手数料料金 & 記述式 & - & $n=109$ \\
\hline \begin{tabular}{l|l}
11 & 有料化指定袋の販売枚数 \\
\end{tabular} & 記述式 & - & $n=103$ \\
\hline \begin{tabular}{|l|l|}
12 & 有料化指定袋の金額 \\
\end{tabular} & 記述式 & - & $n=104$ \\
\hline 13 家庭ごみ有料化の施行時期 & 記述式 & - & $\mathrm{n}=75$ \\
\hline \begin{tabular}{|l|l|}
14 & 有料化実施前後の家庭ごみの量 \\
\end{tabular} & 記述式 & - & $\mathrm{n}=68$ \\
\hline 15 有料化実施前後の不法投棄の量 & 記述式 & - & $\mathrm{n}=26$ \\
\hline 16 有料化実施前後の事業費 & 記述式 & - & $\mathrm{n}=63$ \\
\hline \multicolumn{4}{|l|}{ 審議段階及び説明会に関する事項 } \\
\hline \begin{tabular}{|l|l|}
17 & 資料保存の有無 \\
\end{tabular} & 選択式 & 単数回答 & $\mathrm{n}=110$ \\
\hline \begin{tabular}{|l|l}
18 & 資料の閲覧方法 \\
\end{tabular} & 選択式 & 複数回答 & $\mathrm{n}=53$ \\
\hline 19 閲覧不可能な理由 & 記述式 & - & $\mathrm{n}=8$ \\
\hline \begin{tabular}{|l|l|}
20 & 不保存理由 \\
\end{tabular} & 選択式 & 単数回答 & $\mathrm{n}=25$ \\
\hline 21 有料化に関する市民説明会の回数と実施年 & 記述式 & - & $\mathrm{n}=65$ \\
\hline 22使途説明内容の市民説明会の回数と実施年 & 記述式 & - & $\mathrm{n}=56$ \\
\hline 23 説明会の内容 & 記述式 & - & $\mathrm{n}=55$ \\
\hline \multicolumn{4}{|l|}{ 手数料収入の使途に関する事項 } \\
\hline 24 使途の内容について & 記述式 & - & $n=103$ \\
\hline 25 使途項目の総額と有料化手数料の割合 & 記述式 & - & $n=63$ \\
\hline 26使途項目が新規か継続か、継続なら増額か & 選択式 & 単数回答 & $\mathrm{n}=64$ \\
\hline 27 使途内容の決定の過程 & 記述式 & - & $\mathrm{n}=94$ \\
\hline 28 資料の閲覧方法・範囲 & 記述式 & - & $\mathrm{n}=96$ \\
\hline \begin{tabular}{|l|l|}
29 & 一部非公開の理由 \\
\end{tabular} & 記述式 & - & $\mathrm{n}=3$ \\
\hline 30 使途公開 $の$ 有無 & 選択式 & 単数回答 & $n=100$ \\
\hline 31 公開方法 & 選択式 & 複数回答 & $\mathrm{n}=52$ \\
\hline 32 非公開の理由 & 選択式 & 複数回答 & $\mathrm{n}=36$ \\
\hline \begin{tabular}{|l|l}
33 & 公開内容 \\
\end{tabular} & 選択式 & 複数回答 & $\mathrm{n}=48$ \\
\hline \multicolumn{4}{|l|}{ 今芢の課題に関する事項 } \\
\hline \begin{tabular}{|l|l|}
34 & 手数料使途決定における今後の課題 \\
\end{tabular} & 記述式 & - & $\mathrm{n}=8$ \\
\hline \begin{tabular}{|l|l|l|l}
35 & 数料使途の情報公開における今後の課題 \\
\end{tabular} & 記述式 & - & $\mathrm{n}=3$ \\
\hline
\end{tabular}


これは，手数料収入を特定財源や基金などにすること で, 徵収した手数料の使途を, 市民に具体的に説明する 必要性を認識する市が, 増えたためと推察される

\section{b) 手数料使途の内容}

表-2 に，手数料の使途項目を示す．なお，使途項目の 中には，該当する市が 88 市と，前述の「使途限定あり」 の79市より多い項目もあるが，これは，「制度的に使途 を限定しているわけではないが，予算運用としてごみ処 理費の財源としている」市もあるからである.

使途項目で一番多いのは，「ごみ収集・処理費用」で 88 市 $(85 \%)$ である. この項目が一番多くなるのは予想 されたことであるが，この項目を「使途項目としない」 市が 15\%あることにも注目される.つまり, 有料化は「ご み収集・処理費用に充てるために実施するのではない」 という市が, 少数ながら存在するということである.「ご み減量化推進費用」や「リサイクル推進費用」を使途項 目とする市は各 2 割程度存在し，また「ごみ関連以外」 の「美化，環境教育等」や「環境施策」など（「基金」の 一部も）を使途項目にする市も少数存在する. このよう に, 手数料の使途項目は多様であり, 市民一の丁寧な説 明が必要と考えられる.

\section{c) 使途項目は新規か継続か}

使途項目が，新規か（有料化を実施後に新たに始めた 事業に, 有料化手数料を充当), 継続か (以前加行って いた事業に，有料化手数料を充当）を質問した結果を，

表-3 に示寸. 新規が 3 割程度あり, 有料化の手数料で, 新規に始められた事業が少なくないことがわかる.

表-3で「継続」と回答された使途項目について, 有料 化実施後の事業費の増減を, 表-4に示寸.「増加」の使 途項目が約 5 割に達する。つまり「継続」であっても, 単に今まで行ってきた事業に有料化手数料収入を充てる のではなく，事業費を増加することによってより充実し た事業を行う市が少なくないことがわかる.

\section{d）使途項目の事業費に対する手数料収入の割合}

表 -5 に, 使途項目の事業費に対する手数料収入の割合

表-2 手数料の使途項目（複数回答可）（ $\mathrm{n}=103 ）$

\begin{tabular}{|l|c|}
\hline \multicolumn{1}{|c|}{ 使途項目 } & 市数 \\
\hline ごみ収集・処理費用 & 88 \\
\hline 有料化実施費用 & 41 \\
\hline ごみ減量化推進費用 & 23 \\
\hline リサクル推進費用 & 18 \\
\hline 不法投棄対策費用 & 9 \\
\hline 基金 & 8 \\
\hline 美化、環境教育等 & 7 \\
\hline 環境施策 & 4 \\
\hline 地域活動 & 1 \\
\hline その他 & 4 \\
\hline 使途不特定 & 3 \\
\hline
\end{tabular}

を示す，該当するすべての使途項目について回答いただ いた 56 市についての結果である（使途項目の合計 145 項目). 手数料収入の割合が，100\%の使途項目が一番多 く, 次いで $10 \%$ 以上 $50 \%$ 未満の使途項目であった.

\section{（2）手数料使途の情報公開}

\section{a）家庭ごみ有料化の審議の情報公開}

家庭ごみ有料化の審議資料の保存の有無とその資料の 閲覧可否を質問したところ，110市のうち，「保存かつ閲 覧可能」が 53 市，「保存しているが閲覧不可」が 8 市， 「保存していない」が 25 市，不明が 24 市であった.

「保存から閲覧可能」な 53 市に, 審議資料の閲覧方法 を質問した結果を，表-6に示寸。「直接（訪問による閲 覧)」が最も多く, 次いで「HP (での閲覧)」,「情報公開 請求 (による閲覽)」の順であった. 市民にとっては「HP (での閲覧)」が最も便利な場合が多いであろうから,こ の方法の更なる普及が望まれる.

「保存しているが閲覧不可」な 8 市に, 閲覧不可な理由 を質問した結果を, 表-7 に示寸 (表-7 中の「分類」とは, アンケート回答内容を著者が分類したものであり, 後出 の表-12 及び表-13 も同様)。合併等による「資料の未整 理」が理由の市と，「条例での規定がない等」が理由の市 とが，半々であった。

\section{b) 手数料使途内容の決定段階}

手数料使途の内容（使途項目・具体的内容・金額）の 方針や詳細が，主にどの段階で実質的に決定したのかを 質問した結果を，表-8に示寸.

表-3 使途項目は新規か継続か

\begin{tabular}{|c|c|c|}
\hline & 使途項目数 & 割合 $(\%)$ \\
\hline 新規 & 63 & 31.7 \\
\hline 継続 & 115 & 57.8 \\
\hline その他 & 21 & 10.5 \\
\hline 計 & 199 & 100 \\
\hline
\end{tabular}

表-4「継続」使途項目の事業費増減

\begin{tabular}{|c|c|c|}
\hline \multicolumn{3}{|c|}{ 事業費増減 } \\
\hline $\begin{array}{c}\text { 増加の使途 } \\
\text { 項目数 }\end{array}$ & $\begin{array}{c}\text { 減少の使 } \\
\text { 途項目数 }\end{array}$ & $\begin{array}{c}\text { 横ばいの使 } \\
\text { 途項目数 }\end{array}$ \\
\hline 53 & 11 & 43 \\
\hline
\end{tabular}

表-5 使途項目の事業費に対する手数料収入の割合

\begin{tabular}{|l|c|c|}
\hline \multicolumn{1}{|c|}{ 手数料収入の割合 } & 使途項目数 & 割合 $(\%)$ \\
\hline $100 \%$ & 56 & 38.6 \\
\hline $50 \%$ 以 $100 \%$ 未満 & 16 & 11 \\
\hline $10 \%$ 以 $50 \%$ 未満 & 45 & 31 \\
\hline $1 \%$ 上 $10 \%$ 未満 & 16 & 11 \\
\hline $1 \%$ 未満 & 3 & 2.1 \\
\hline その他 $(100 \%$ 未満だが数值不明 $)$ & 9 & 6.3 \\
\hline 計 & 145 & 100 \\
\hline
\end{tabular}


使途項目・具体的内容・金額の，方針も詳細も，「(審 議会答申後に議会に条例案提出までの) 自治体での検討」 の段階で実質的に決定する市が，一番多い.ただし，二 番目に多いのは様々であり，「使途項目・具体的内容・金 額，の方針」は「審議会」，「使途項目・具体的内容，の 詳細」は「議会」,「金額の詳細」は「有料化実施後」で あった。

\section{c）手数料使途内容の決定過程の情報公開}

手数料使途内容の決定過程の資料の閲覧可否について 質問したところ，110市のうち，閲覧可能が 54 市，閲覧 不可が 24 市，不明・無回答が 32 市であった. 閲覧可能 と回答した 54 市のうち, 閲覧範囲と閲覧方法（最も当て はまるもの 1つ)について回答いただいた 35〜40 市につ いて, 手数料使途内容の決定過程の資料の閲覧範囲と閲 覧方法を，表-9に示す.

閲覧範囲は「全て」という市が，75\%〜81\%と多い. ただし，閲覧範囲は「全て」の市であっても，閲覧方法 については, HP で可能な市の割合は,「方針」で $20 \%$ 40\%，「詳細」で3\%～25\%であり，市役所でのコピーか 情報公開請求かが必要な市の方が多い. 市民にとっては

「HP (での閲覧)」が最も便利な場合が多いであろうか ら，この方法の更なる普及が望まれる.

\section{d）手数料使途実績の情報公開}

手数料使途実績の情報公開の有無について質問したと ころ，110市のうち，公開が 52 市，非公開が 36 市，不 明・無回答が 32 市であった。

なお人口別では表-10 に示寸通りであり，人口が多い 市ほど，手数料使途実績を情報公開する市の割合が高く

表-6「保存かつ閲覽可能」市の審議資料閲覽方法

(複数回答可) $(\mathrm{n}=53)$

\begin{tabular}{|c|c|c|c|c|}
\hline 直接 & HP & $\begin{array}{l}\text { 情報公開 } \\
\text { 請求 }\end{array}$ & 郵送 & 図書館 \\
\hline 27 & 19 & 16 & 5 & 1 \\
\hline
\end{tabular}

表-7「保存しているが閲覽不可」な市の閲覽不可な理由 $(\mathrm{n}=8)$

\begin{tabular}{|c|c|}
\hline 分類 & 保存しているが閲覧不可である理由 \\
\hline \multirow{4}{*}{$\begin{array}{c}\text { 資料の未整理 } \\
(\mathrm{n}=4)\end{array}$} & 閲覧により過程がわかるような形では，資料が整理さ \\
\hline & $\begin{array}{l}\text { 事務処理として, 保存しており, 閲覧可能な状態では } \\
\text { ない }\end{array}$ \\
\hline & $\begin{array}{l}\text { 合併時にその他の事項とともに協議・保管されてお } \\
\text { り, 膨大な量になるた, 資料の整理が必要なため }\end{array}$ \\
\hline & 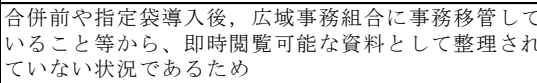 \\
\hline \multirow{4}{*}{$\begin{array}{l}\text { 条例での規定 } \\
\text { がない等 }(\mathrm{n}=4)\end{array}$} & 公開を前提としない内部資料等であるから \\
\hline & 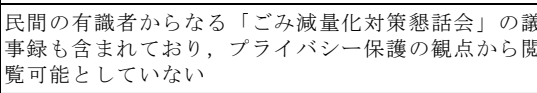 \\
\hline & $\begin{array}{l}\text { 廃棄物減量等推進協議会で審議しているがその条例の } \\
\text { 中でめ定めていないた的 }\end{array}$ \\
\hline & 情報開示が市内在住者対象だから \\
\hline
\end{tabular}

なる傾向が認められた。

「公開」と回答した 52 市に, 情報公開の内容を質問し たところ，42 市から回答があり，その結果を表-11に示 寸.「各使途項目の金額」や「使途の合計金額」を公開し ている市が多い事がわかる。 なお「その他」の 5 市は,

「課全体の予算を公開」,「ごみ袋の手数料収入額がごみ 処理経費に充てられていることがわかるだけ」という， おおまかな公開の 2 市と,「金額は各使途項目ではなく, より細かく各事業の金額を記載. 各使途の詳細について は，代表的な事業の説明も記載」，「予算書において使途 事業を明記」,「太陽光発電補助金を 1 キロ 3 万円から 4 万円に拡充」という詳しい公開の 3 市に区分された.

\section{e）手数料使途の決定および情報公開の今後の課題}

手数料使途の決定についての今後の課題を質問したと ころ, 8 市から回答があり, その結果を表-12 に示寸.「市 民還元事業を固定化せず常に見直していく」や「新たな 施策に手数料を充当すべき」などの「事業の見直し」や，

「今後のごみ処理広域化に伴う手数料の統一」や「地域 に応じた手数料金額の設定」などの「手数料金額の見直 し」や,「ごみ減量の市民努力の, 手数料使途や金額への 還元」という「市民努力の還元」が，今後の課題とされ ている.

手数料使途の情報公開についての今後の課題を質問し たところ, 3 市から回答があり, その結果を表-13 に示す.

「使途の周知徹底」や「掲載上のずれ (事務組合のため)」 とともに,「一般会計の難しさ（特定財源にしていないた め)」が挙げられた. 市民への説明のしやすさという点で, ごみ処理手数料は，特定財源とすることが望ましいと考

表-8 手数料使途内容の決定段階 $(\mathrm{n}=81) \quad$ －数值は市数 $>$

\begin{tabular}{|c|c|c|c|c|c|c|c|c|}
\hline & & 審議会 & \begin{tabular}{|l} 
自治体で \\
の検討
\end{tabular} & 議会 & $\begin{array}{l}\text { 議会後～有 } \\
\text { 料化㬰施前 }\end{array}$ & $\begin{array}{l}\text { 有料化実 } \\
\text { 施後 }\end{array}$ & $\begin{array}{c}\text { 一部無回 } \\
\text { 答 }\end{array}$ & 計 \\
\hline \multirow{2}{*}{ 使途項目 } & 方針 & 30 & 37 & 9 & 1 & 2 & 2 & 81 \\
\hline & 詳細 & 2 & 63 & 7 & 3 & 3 & 3 & 81 \\
\hline \multirow{2}{*}{ 具体的内容 } & 方針 & 19 & 43 & 12 & 2 & 3 & 2 & 81 \\
\hline & 詳細 & 1 & 51 & 15 & 3 & 8 & 3 & 81 \\
\hline \multirow{2}{*}{ 金額 } & 方針 & 17 & 46 & 7 & 3 & 5 & 3 & 81 \\
\hline & 詳細 & 0 & 38 & 15 & 4 & 20 & 4 & 81 \\
\hline
\end{tabular}

表-9 手数料使途内容の決定過程の資料の閲覧範囲と閲覧方法 <数值は市数 $>$

\begin{tabular}{|c|c|c|c|c|c|c|c|c|c|}
\hline & \multirow{2}{*}{\multicolumn{2}{|c|}{ 閲覧範囲 }} & \multicolumn{4}{|c|}{ 閲覧方法 } & \multirow[b]{2}{*}{ 広報 } & \multirow[b]{2}{*}{ その他 } \\
\hline & & & & HP & $\begin{array}{c}\text { 市(ユ } \\
\text { ピー }\end{array}$ & $\begin{array}{l}\text { 市 (ユ } \\
\text { ピー不 }\end{array}$ & 情報公 & & \\
\hline \multirow{4}{*}{$\begin{array}{l}\text { 使途 } \\
\text { 項目 }\end{array}$} & \multirow{2}{*}{$\begin{array}{c}\text { 方針 } \\
(\mathrm{n}=37)\end{array}$} & 全て & 30 & 12 & 8 & 1 & 7 & 0 & 2 \\
\hline & & 一部 & 7 & 1 & 0 & 1 & 4 & 1 & 0 \\
\hline & \multirow{2}{*}{$\begin{array}{l}\text { 詳細 } \\
(\mathrm{n}=35)\end{array}$} & 全て & 28 & 7 & 7 & 2 & 10 & 0 & 2 \\
\hline & & 一部 & 7 & 0 & 1 & 1 & 4 & 1 & 0 \\
\hline \multirow{4}{*}{$\begin{array}{l}\text { 具体 } \\
\text { 的内 } \\
\text { 容 }\end{array}$} & \multirow{2}{*}{$\begin{array}{c}\text { 方針 } \\
(\mathrm{n}=37)\end{array}$} & 全て & 28 & 10 & 7 & 1 & 7 & 0 & 3 \\
\hline & & 一部 & 9 & 2 & 0 & 1 & 5 & 1 & 0 \\
\hline & \multirow{2}{*}{$\begin{array}{l}\text { 詳細 } \\
(\mathrm{n}=37)\end{array}$} & 全て & 29 & 5 & 7 & 2 & 11 & 0 & 4 \\
\hline & & 一部 & 8 & 1 & 1 & 1 & 4 & 1 & 0 \\
\hline \multirow{4}{*}{ 金額 } & \multirow{2}{*}{$\begin{array}{l}\text { 方針 } \\
(\mathrm{n}=36)\end{array}$} & 全て & 27 & 7 & 8 & 1 & 8 & 0 & 3 \\
\hline & & 一部 & 9 & 2 & 0 & 1 & 5 & 1 & 0 \\
\hline & \multirow{2}{*}{$\begin{array}{l}\text { 詳細 } \\
(\mathrm{n}=40)\end{array}$} & 全て & 32 & 5 & 10 & 2 & 12 & 0 & 3 \\
\hline & & 一一部 & 8 & 1 & 1 & 1 & 4 & 1 & 0 \\
\hline
\end{tabular}




\section{えられる。}

\section{f）手数料使途の情報公開とごみ減量の関係}

手数料使途の情報公開とごみ減量とは，どんな関係に あるのか. もちろん，ごみ減量には他の多くの要因が関 係しているであろうが，手数料使途の情報公開の程度と の関係を検討した研究は，これまで見当たらない，そこ で検討の第一歩として本稿では, 手数料使途の情報公開 との関係に限定して検討した。

まず，手数料使途実績の情報公開の有無とごみ減量の 関係について調べた. なおごみ減量の指標は,

ごみ増加率 $=(($ 有料化実施 1 年目の家庭ごみ量一有 料化実施 1 年前の家庭ごみ量) / (有料化実施 1 年 前の家庭ごみ量)） $\times 100 ）$

とした. 家庭ごみ量は年度単位で集計されているので, 有料化実施が年度途中からの場合は，実施前年度と実施 翌年度から算出した. 手数料使途実績の有無, 該当する 両年度の家庭ごみ量, ともに回答いただいた 56 市につい て, 手数料使途実績の情報公開の有無とごみ減量の関係 を，表-14 に示寸．情報公開を行う市の方が，行わない 市よりも, ごみ増加率の平均值は小さく（マイナスなの で, ごみ減量の程度が大きい), 平均值の差の検定 (ウエ ルチの $\mathrm{t}$ 検定）でも $5 \%$ 有意であった（統計量 $\mathrm{T}=2.23$,

自由度 $\mathrm{f}=36.2$.

次に手数料使途の情報公開の評価の総合点と, ごみ増 加率との関係を求めた．手数料使途の情報公開の評価の 総合点は, 「手数料使途決定過程の情報公開の評価点」を 50 点満点,「手数料使途実績の情報公開の評価点」を 50 点満点として, 両者の合計点 (100 点満点) で算出した.

「使途決定過程」と「使途実績」とは情報公開の点で同 程度に重要と, 著者が考えたためである. なお上記表-14

表-10 人口別の手数料使途実績の情報公開の有無 $(n=110)$

\begin{tabular}{|c|c|c|c|c|c|c|}
\hline \multirow{2}{*}{ 人口 } & \multicolumn{4}{|c|}{ 使途実績の情報公開の有無 } & \multirow{2}{*}{ 市数 } & \multirow{2}{*}{\begin{tabular}{|c} 
使途実績の \\
情報公開の \\
割合 $\%$ \%)
\end{tabular}} \\
\hline & 公開 & 非公開 & 不明 & 無回答 & & \\
\hline 100 万人以上 & 4 & 0 & 0 & 0 & 4 & 100 \\
\hline \begin{tabular}{|l|}
10 万人以上 \\
100 万人未満 \\
\end{tabular} & 16 & 3 & 0 & 3 & 22 & 73 \\
\hline \begin{tabular}{|l}
5 万人以上 10 \\
万人未満
\end{tabular} & 24 & 12 & 4 & 3 & 43 & 56 \\
\hline 5 万人未満 & 8 & 21 & 8 & 4 & 41 & 20 \\
\hline 計 & 52 & 36 & 12 & 10 & 110 & 47 \\
\hline
\end{tabular}

表-11 手数料使途実績の情報公開の内容（複数回答可） $(n=42) \quad$ ＼cjkstart数值は市数>

\begin{tabular}{|c|c|c|c|}
\hline $\begin{array}{c}\text { 使途の合計 } \\
\text { 金額 }\end{array}$ & $\begin{array}{c}\text { 各使途項目 } \\
\text { の金額 }\end{array}$ & $\begin{array}{c}\text { 各使途項目の } \\
\text { 金額割合 }\end{array}$ & 使途項目のみ \\
\hline 29 & 30 & 6 & 8 \\
\hline $\begin{array}{c}\text { 各使途の詳 } \\
\text { 細 }\end{array}$ & $\begin{array}{c}\text { 補助金の団 } \\
\text { 体名 }\end{array}$ & $\begin{array}{c}\text { 補助金先の決 } \\
\text { 定プロセス }\end{array}$ & その他 \\
\hline 6 & 1 & 0 & 5 \\
\hline
\end{tabular}

の対象 56 市のうち，「使途決定過程」の情報公開につい て無回答の 3 市を除いた, 53 市を対象に分析した.

手数料使途決定過程の情報公開の評価点の算出方法を, 表-15 に示す．情報公開の内容は，使途項目の方針およ び詳細，具体的内容の方針および詳細，金額の方針およ び詳細の 6 項目とした. そして各項目の評価点を，市民 の情報入手の容易さの順に，HPに掲載が 10 点，市の広 報に掲載が 7 点, 市役所で閲覧がコピー可は 5 点, コピ 一不可は 2.5 点, 情報公開請求で入手が 3 点, 情報公開 しないが 0 点とした（情報公開の範囲が「一部」の場合 は，それぞれ半分の評価点). なお「資料が存在しない， 不明」などの回答は，結果的に「情報公開しない」と同 等とみなして，0点とした. また分析対象の 53 市に，表 -9で閲覧方法が「その他」と回答した市が 1 市含まれる が，この市は「図書館での閲覧」のため,「市役所で閲覧 (コピー可)」に含めた．なお回答では,「最も当てはま る情報公開方法 1 つ」を選択いただいたので, 6 項目す べてが HP 掲載の場合が，最高の 60 点となる. こうして 求めた評価点に, $0.833(=50 / 60)$ を乗じて, 「手数料使途

表-12 手数料使途の決定についての今後の課題 $(\mathrm{n}=8)$

\begin{tabular}{|c|c|}
\hline 分類 & 手数料使途の決定についての今後の課題 \\
\hline \multirow{4}{*}{$\begin{array}{l}\text { 事業の見 } \\
\text { 直し } \\
(\mathrm{n}=4)\end{array}$} & $\begin{array}{l}\text { 市民還元事業を固定したものと考えるのではなく，歳入 } \\
\text { 額を考慮しながら，常に見直していく必要がある. }\end{array}$ \\
\hline & $\begin{array}{l}\text { 今後の手数料の使途の決定につきましては, 家庭ごみ有 } \\
\text { 料化制度導入当初の方針に従いながらも，本市の廃棄物 } \\
\text { 処理や環境政策の両方の観点から，その時に必要な経費 } \\
\text { に充当できるように検討していく必要がある. }\end{array}$ \\
\hline & $\begin{array}{l}\text { 今後とも, 使途項目に基づき, 市民生活に密着した効果 } \\
\text { 的・効率的事業を実施していく必要がある. }\end{array}$ \\
\hline & $\begin{array}{l}\text { 手数料改定による財源を新たな施策に充当することで市 } \\
\text { 民への理解を得ることも検討していくことが必要であ } \\
\text { る. }\end{array}$ \\
\hline $\begin{array}{c}\text { 市民の努 } \\
\text { 力の還元 } \\
(n=1)\end{array}$ & $\begin{array}{l}\text { 有料化以降, 家庭から出るもえるごみの量は減ったが, } \\
\text { 指定ごみ袋の価格には反映されていない。市民の努力 } \\
\text { が, 手数料の使途や価格に還元できるしくみができれ } \\
\text { ば, ごみ有料化に対する住民のコンセンサスが得やす } \\
\text { い. }\end{array}$ \\
\hline \multirow{3}{*}{$\begin{array}{c}\text { 手数料 } の \\
\text { 見直し } \\
(\mathrm{n}=3)\end{array}$} & $\begin{array}{l}\text { ごみの焼却及び処理に関わる経費（委託を含む）を費用 } \\
\text { 対効果を考慮した適正処理を第一に実施するよう毎年検 } \\
\text { 討している.その上に立って, 市民負担となる手数料の } \\
\text { 見直しをしていくことが必要である. }\end{array}$ \\
\hline & $\begin{array}{l}\text { 手数料使途については、現状のごみ処理施設の維持管理 } \\
\text { 費で妥当であるが，手数料の金額設定については全国的 } \\
\text { な状況をふまえながら地域に応じた設定を行っていなけ } \\
\text { ればならないと思っている. }\end{array}$ \\
\hline & $\begin{array}{l}\text { 今後はごみ処理の広域化を計画していく中で, 手数料の } \\
\text { 統一化を近隣自治体と協議していくことが課題 }\end{array}$ \\
\hline
\end{tabular}

表-13 手数料使途の情報公開についての今後の課題 $(\mathrm{n}=3)$

\begin{tabular}{|c|c|}
\hline 分類 & 手数料使途の情報公開についての今後の課題 $\quad(n=3)$ \\
\hline $\begin{array}{c}\text { 使途の周知徽底 } \\
(\mathrm{n}=1)\end{array}$ & $\begin{array}{l}\text { 今後とも使途につき, 積極的に市民の皆様に周知する必要があ } \\
\text { る. }\end{array}$ \\
\hline $\begin{array}{l}\text { 一般会計の難しさ } \\
(\mathrm{n}=1)\end{array}$ & $\begin{array}{l}\text { 有料化に伴う歳入については, 項目がはっきりしているが, 特定 } \\
\text { 財源にはしていないた，歳出の区別が難しく，市民に説明する } \\
\text { さい分かりにくい. }\end{array}$ \\
\hline $\begin{array}{l}\text { 掲載上のずれ } \\
\text { (n=1) }\end{array}$ & $\begin{array}{l}\text { 有料化の収支報告として広報で掲載している関係上，事務組合負 } \\
\text { 担金等を含む「塺芥処理経費」を同時に掲載していませんので一 } \\
\text { 部の方 (団体) の誤解を招く恐れがある. }\end{array}$ \\
\hline
\end{tabular}


決定過程の情報公開の評価点（50 点満点）」とした. 53 市の「手数料使途決定過程の情報公開の評価点 (50 点満 点)」は, 0 点 50 点まで幅広く分布し, 平均 11.4 点で あった.

手数料使途実績の情報公開の評価点の算出方法を，表 -16 に示寸．情報公開の内容は，使途の合計金額，各使 途項目の金額，各使途項目の金額の割合，使途項目，各 使途の詳細の 5 項目とした. そしてこれら 5 項目の相対 的重要度 (例えば, 使途の合計金額よりも, 各使途項目 の金額のほうが，情報量が多いので，相対的に高い点数 にする）と，各情報公開方法についての市民の情報入手 の相対的容易さ（例えば，HP 掲載のほうが，情報公開 請求より情報入手ははるかに容易なので, 相対的に高い 点数にする）とを考慮して, 各評価点を表-16 のように 設定した. また分析対象の 53 市に, 表-11で情報公開の 内容が「補助金の団体名」と回答した 1 市が含まれるが,

「補助金の団体名」は「各使途の詳細」に含めた。なお 情報公開方法が複数ある場合は, 最も評価点の高い情報 公開方法を,その市の代表的な情報公開方法とみなして, その評価点を用いた（手数料使途決定過程の情報公開の 評価点の算出方法と同様にするため). 5 項目すべてが $\mathrm{HP}$ 掲載の場合が, 最高の 26 点となる. こうして求めた 評価点に, 1.923(=50/26)を乗じて, 「手数料使途実績の情 報公開の評価点 (50 点満点)」とした. 53 市の「手数料 使途決定過程の情報公開の評価点 (50 点満点)」は, 0 点〜21 点まで幅広く分布し, 平均 4.8 点であった.

こうして求めた「手数料使途決定過程の情報公開の評 価点 (50 点満点)」と「手数料使途実績の情報公開の評 価点（50 点満点）とを合計して,「手数料使途の情報公 開の評価の総合点 (100 点満点)」を算出した. 0 点 90.4 点まで幅広く分布し, 平均 20.3 点であった.

そして, この「手数料使途の情報公開の評価の総合点

表-14 手数料使途実績の情報公開の有無とごみ減量の関係 $(\mathrm{n}=56)$

\begin{tabular}{|c|c|c|}
\hline & 使途公開 & 使途非公開 \\
\hline 市数 & 35 & 21 \\
\hline ごみ増加率の平均値 $(\%)$ & -17.9 & -10.5 \\
\hline ごみ増加率の標準偏差 $(\%)$ & 10.6 & 12.8 \\
\hline
\end{tabular}

表-15 手数料使途決定過程の情報公開の評価点の算出方法

(数值の単位 : 点)

\begin{tabular}{|c|c|c|c|c|c|}
\hline \multirow{2}{*}{ 情報公開の内容 } & \multicolumn{5}{|c|}{ 情報公開の有無・方法 } \\
\cline { 2 - 7 } & H P & 広報 & 市役所 & 情報公開請求 & 情報公開せす寸 \\
\hline 使途項目 (方針) & 10 & 7 & 5 & 3 & 0 \\
\hline 使途項目 (詳細) & 10 & 7 & 5 & 3 & 0 \\
\hline 具体的内容 (方針) & 10 & 7 & 5 & 3 & 0 \\
\hline 具体的内容 (詳細) & 10 & 7 & 5 & 3 & 0 \\
\hline 金額 (方針) & 10 & 7 & 5 & 3 & 0 \\
\hline 金額 (詳細) & 10 & 7 & 5 & 3 & 0 \\
\hline
\end{tabular}

(100 点満点)」とごみ増加率との関係を図-1 に示した $(\mathrm{n}=53)$. 手数料使途の情報公開の総合点とごみ増加率と の相関係数は-0.33 であり，5\%有意であった. したがっ て, 両者の間には統計的に有意な関連が認められる.

なお回帰式を求めたところ,

$$
\mathrm{y}=-0.168 \mathrm{x}-11.338
$$

であった. 手数料使途の情報公開の総合点が $\mathrm{x}$ ，ごみ増 加率 (\%) が y である. 右下がりの直線であり, 手数料 使途の情報公開の総合点が高いほど，ごみ増加率が低く なる（ごみが減量する）ことになる。

\section{4. まとめ}

本稿では，家庭ごみ有料化における手数料使途の実態 や情報公開の詳細な全国的傾向を，有料化施行時期が近 年 (2005 年〜2009 年) の市へのアンケート調査によって 把握した．得られた主な知見は以下の通りである.

1) 手数料収入は, 特別会計でなく一般会計に入る. た だし, 使途を「限定なし」の市の割合は $25 \%$ であり， 先行研究での知見である「6 年前は $59 \%$ 」から，大 幅に減少した. これは，手数料収入を特定財源や基 金などにすることで，徵収した手数料の使途を，市 民に具体的に説明する必要性を認識する市が，増え

表-16 手数料使途実績の情報公開の評価点の算出方法

(数值の単位: 点)

\begin{tabular}{|c|c|c|c|c|c|c|}
\hline \multirow[b]{2}{*}{$\begin{array}{c}\text { 情報公開の } \\
\text { 内容 }\end{array}$} & \multicolumn{6}{|c|}{ 情報公開の有無・方法 } \\
\hline & HP & 広報 & $\begin{array}{c}\text { 市民説 } \\
\text { 明会 }\end{array}$ & 市役所 & \begin{tabular}{|c|}
$\begin{array}{c}\text { 情報公開 } \\
\text { 請求 }\end{array}$ \\
\end{tabular} & $\begin{array}{c}\text { 情報公開 } \\
\text { なし } \\
\end{array}$ \\
\hline 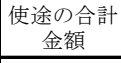 & 3 & 2. 1 & 1.8 & 1.5 & 0.9 & 0 \\
\hline 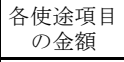 & 10 & 7 & 6 & 5 & 3 & 0 \\
\hline $\begin{array}{l}\text { 各使途項目 } \\
\text { の金額割合 }\end{array}$ & 5 & 3.5 & 3 & 2.5 & 1.5 & 0 \\
\hline 使途項目 & 3 & 2.1 & 1.8 & 1.5 & 0.9 & 0 \\
\hline $\begin{array}{c}\text { 各使途の詳 } \\
\text { 細 }\end{array}$ & 5 & 3.5 & 3 & 2.5 & 1.5 & 0 \\
\hline
\end{tabular}

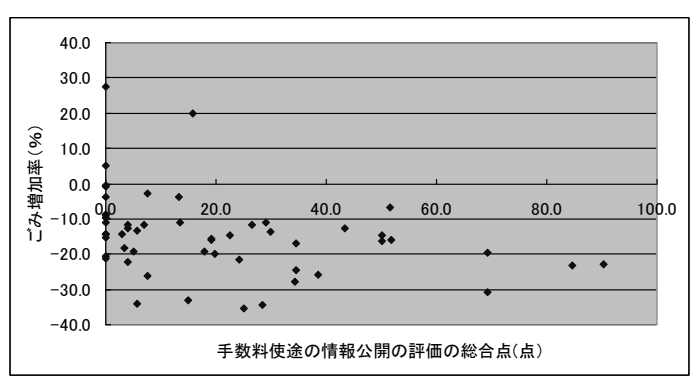

図-1 手数料使途の情報公開の評価の総合点とごみ増加率との 関係 $(\mathrm{n}=53)$ 
たためと推察される.

2) 使途項目で一番多いのは，「ごみ収集・処理費用」 であるが，「ごみ減量化推進費用」や「リサイクル推 進費用」を使途項目とする市は各 2 割程度存在し, また「ごみ関連以外」の「美化，環境教育等」や「環 境施策」などを使途項目にする市も少数存在する.

このように，手数料の使途項目は多様であり，市民 への丁寧な説明が必要と考えられる.

3) 使途項目が, 新規が 3 割程度あり, 有料化の手数料

で，新規に始められた事業が少なくない.

なお継続であっても, 事業費が増加している使途項 目が約 5 割あり，単に今まで行ってきた事業に有料 化手数料収入を充てるのではなく，事業費を増加す ることによってより充実した事業を行う市が少なく ない.

4) 手数料使途内容は, 使途項目 - 具体的内容・金額の, 方針も詳細も，「(審議会答申後に議会に条例案提出 までの）自治体での検討」の段階で実質的に決定す る市が，一番多い.

5) 手数料使途内容の決定過程の資料は, 約半数の市で 閲覧可能であった. そして閲覧可能と回答した市の うち, 閲覧範囲は「全て」という市が 8 割程度存在 する.ただし，閲覧範囲は「全て」の市であっても， 閲覧方法については，HP で可能な市よりも，市役 所でのコピーか情報公開請求かが必要な市の方が多 い. 市民にとっては「HP (での閲覧)」が最も便利 な場合が多いであろうから，この方法の更なる普及 が望まれる。

6) 手数料使途実績の情報公開は, 半数弱の市で実施さ れており，人口の多い市ほど情報公開の市の割合が 高い傾向にある. 情報公開の内容は,「各使途項目の 割合」や「使途の合計金額」が多い.

7) 手数料使途の決定の今後の課題は，「事業の見直 し」・手数料金額の見直し」・「市民努力八の還元」 であり, 手数料使途の情報公開の今後の課題は,「特 定財源にしていないための，一般会計の難しさ」な どであった．市民への説明のしやすさという点で， ごタ処理手数料は，特定財源とすることが望ましい と考えられる.

8) 手数料使途実績の情報公開を行う市の方が, 行わな い市よりも，ごみ増加率の平均值は小さく（マイナ スなので，ごみ減量の程度が大きい)，この傾向は， 統計的に有意であった。

9) 使途内容の「使途項目」・「具体的内容」・「使途金額」 の回答，「使途内容の決定の過程」・審議資料の閲覧 可否」・審議資料の閲覧方法」の回答，使途実績の

「情報公開の有無」・公開方法」「公開の内容」の回 答, の計 9 個の評価項目の各評価点の総合点とごみ
増加率との間には，統計的に有意な関連が認められ た.

本研究で得られた以上の主な知見のうち，家庭ご み有料化の手数料使途の実態と情報公開に関して, 特に重要な知見と筆者が考えるのは，次の 3 点であ る.

1 つ目は，家庭ごみ有料化の手数料の使途を，市民に わかりやすくしている市が増えていることがわかったこ とである. 手数料として徴収されたお金が，具体的に何 に使われているのかを，市民に説明することは，家庭ご み有料化を円滑に進める上で重要なことである.

2 つ目は，家庭ごみ有料化で手数料として徵収された お金は，単にごみ処理費用の一部に充てられるのではな く，新規事業の実施や継続事業の充実に使われている市 が少なくないことがわかったことである．有料化が市民 のごみ減量への経済的誘因になると同時に，ごみ施策の 充実につながれば，より意義深いので，こうした傾向は 望ましいことと考える.

3 つ目は，手数料使途の情報公開が進むほど，ごみ減 量が促進される傾向が，統計的に有意に認められたこと である．情報公開を進めることで，行政側はいい意味で 緊張感を持ってごみ処理に取り組み，市民は手数料使途 などの情報を得ることで「納得して」ごみ減量に取り組 む，という好循環が生じている可能性がある.この点の 検証は，今後の課題としたい. なお手数料使途の情報公 開の評価の総合点の算出方法については，手数料使途決 定過程と使途実績との重み付け，情報公開方法同士の重 み付け，情報公開内容の分類や重み付けなど，今後のさ らなる検討が必要と考える（市民アンケートなどによる 重夕付けも一案).また, 手数料使途の情報公開の評価の 総合点とごみ減量との関係についても，他の要因との関 連の検討は，今後の課題である.

\section{参考文献}

1) 環境省 : 廃棄物の減量その他その適正な処理に関する施策 の総合的かつ計画的な推進を図るための基本的な方針, 2007.

http://www.env.go.jp/press/press.php?serial=6010

2）環境省大臣官房廃棄物・リサイクル対策部廃棄物対策 課 : 一般廃棄物処理有料化の手引き, 2007. http://www.env.go.jp/recycle/waste/tool_gwd3r/ps/index.html

3）環境省大臣官房廃衰物・リサイクル対策部廃棄物対策課 : 日本の廃棄物処理 (平成 21 年度版), 2011. http://www.env.go.jp/recycle/waste_tech/ippan/h21/index.html

4）山川肇，植田和弘：ごみ有料化研究の成果と課題 : 文献レ ビュー, 廃棄物学会誌, 第 12 巻, 第 4 号, pp.245-258, 2001.

5) Sakai,S., Ikematsu,T., Hirai,Y., Yoshida,H. : Unitchargingprograms for municipal solid waste in Japan, Waste Management, Vol.28, pp.2815-2825, 2008.

6) 天野耕二，松浦篤史:家庭ごみ排出特性に関わる指定袋配布 制度の評価,廃棄物学会論文誌, 第13巻, 第2号, pp.63-70, 
2002.

7) 山川肇, 植田和弘, 寺島泰 : 有料化実施時におけるごみ減 量の影響要因, 廃棄物学会論文誌, Vol. 13,pp.262-270, 2002.

8) 碓井健寛 : 有料化によるごみの発生抑制効果とリサイクル 促進効果, 会計検查研究,Vol.27, pp.245-261,2003.

9) 福岡雅子, 小泉春洋, 山川肇, 高月紘: 透明・半透明袋制導 入時のごみ減量効果及び減量要因の解析, 廃棄物学会論文 誌, 第 15 巻, 第 4 号, pp.266-275, 2004.

10) 佐竹正之, 金谷健 : 家庭ごみ有料化における制度設定プロ セス及び料金設定根拠に関する研究，環境システム研究論 文集, 第36 巻, pp.309-317, 2008.

11）池松達人, 森安洋平, 平井康宏, 酒井 伸一: ごみ減量効果 に寄与するごみ有料化施策の制度設計要因分析，土木学会
論文集 G (環境)，Vol.67, No.6 (環境システム研究論文集, 第39巻)，II_459-II_467, 2011.

12）山谷修作 : ごみ有料化，丸善株式会社，2007.

13) 山谷修作：ごみ見える化 (有料化で推進するごみ減量), 丸 善株式会社, 2010.

14) 山谷修作: 最新・家庭ごみ有料化事情, 月刊廃棄物, 2005 年 9 月号, pp.44-49, 2005.

15) 環境省 : 廃棄物処理技術情報, 2011. http://www.env.go.jp/recycle/waste_tech/index.html

(2012. 8.9 受付)

\section{PRESENT CONDITION AND PUBLICATION OF INFORMATION ON USAGE OF CHARGE OF DISPOSAL OF HOUSEHOLD WASTE}

\section{Nozomi HIKASA and Ken KANAYA}

Purpose of this research is to clear present condition and publication of information on usage of charge of disposal of household waste. Method of this research is questionnaire survey to cities introducing the charging system on disposal of household waste from 2005 to 2009 . Findings of this research are as follows:

1.The charge income enter into the general account, rather than special accounts. But percentage of the city without limitation the usage is only $25 \%$, and this percentage is greatly reduced from $59 \%$ six years ago.

2. About $30 \%$ of the item of usage is the new item. And in about $50 \%$ of the item continued, the project cost increases.

3. About half of the city have published the article on decision-making process of usage of charge. And about half of the city have published the article on actual of usage of charge.

4. Between publication of information on usage of charge and waste reduction, statistically significant association is observed. 